\begin{tabular}{|c|c|c|c|}
\hline \multirow{2}{*}{$\begin{array}{r}\text { Case Reports in } \\
\text { Gastroenterology }\end{array}$} & \multicolumn{2}{|c|}{ Case Rep Gastroenterol 2016;10:292-301 } & \multirow[b]{2}{*}{$\begin{array}{l}\text { Karger } \\
\text { Open access }\end{array}$} \\
\hline & $\begin{array}{l}\text { DOI: 10.1159/000444277 } \\
\text { Published online: June 14, } 2016\end{array}$ & $\begin{array}{l}\text { (c) } 2016 \text { The Author(s) } \\
\text { Published by S. Karger AG, Basel } \\
\text { www.karger.com/crg }\end{array}$ & \\
\hline & $\begin{array}{l}\text { This article is licensed under } \\
\text { International License (CC BY- }- \\
\text { Usage and distribution for comn }\end{array}$ & $\begin{array}{l}\text { nons Attribution-NonCommercia } \\
\text { ger.com/Services/OpenAccessLice } \\
\text { uires written permission. }\end{array}$ & \\
\hline
\end{tabular}

\title{
Concurrent Gastric Adenocarcinoma of Fundic Gland Type and Carcinoma with Lymphoid Stroma: A Rare Case Report
}

\author{
Hee Jeong Cha Kyungbin Kim Misung Kim Hyejeong Choi \\ Young Min Kim Jae Hee Suh \\ Department of Pathology, Ulsan University Hospital, University of Ulsan College of \\ Medicine, Ulsan, Republic of Korea
}

\section{Keywords}

Stomach - Adenocarcinoma of fundic gland type · Carcinoma with lymphoid stroma

\begin{abstract}
Both gastric adenocarcinoma of fundic gland type (ADC-FG) and carcinoma with lymphoid stroma (lymphoepithelioma-like carcinoma, LELC) are relatively rare. Epstein-Barr virus (EBV) has been implicated in the pathogenesis of LELC. However, the pathogenesis of ADC-FG, as well as the role of EBV in the carcinogenesis of LELC, remain unclear and under debate. The current study presents a case of concurrent ADC-FG and LELC in the stomach in a 69-yearold man. Total gastrectomy was performed, and two separate masses were identified. Upon histological and immunohistochemical examination, the mass located in the lower body was determined to be LELC and the mass in the upper body was diagnosed as ADC-FG. The lesions were characterized by different mucin phenotypes and EBV in situ results. In the lowerbody mass, EBV in situ hybridization expression was diffusely strongly positive, but MUC2, MUC5AC, MUC6, and CD10 were all negative. On the other hand, in the upper-body mass, the results were positive for MUC6 but negative for MUC2, MUC5AC, CD10, and EBV by in situ hybridization. The remaining gastric tissue was unremarkable, and perigastric lymph node metastases were absent. Seven months after the gastrectomy, a postoperative computed tomography scan revealed no recurrence or metastasis.




\section{Introduction}

Gastric adenocarcinoma is characterized by broad morphological heterogeneity with cell differentiation. Tumors are separated into intestinal and diffuse types by the Lauren classification [1], and either differentiated or undifferentiated types by the classification of Nakamura et al. [2]. With recent progress in mucin histochemistry, it has been explained that adenocarcinoma of the intestinal type comprises the gastric phenotype [3]. Gastric phenotypes contain the foveolar type, pyloric gland type, and fundic gland type. Among them, there have been only a few reported cases of adenocarcinoma of fundic gland type (ADC-FG) [4, 5]. Recently, some authors have proposed ADC-FG as a new entity of gastric adenocarcinoma $[5,6]$.

Gastric carcinoma with lymphoid stroma, also reported as lymphoepithelioma-like carcinoma (LELC), is a rare and special type of gastric carcinoma that was first described by Watanabe et al. [7] in 1976. More than 80\% of cases of this tumor have been associated with infection with Epstein-Barr virus (EBV), and the prognosis for patients with this tumor is reportedly better than that for patients with typical gastric cancers [8].

Both ADC-FG and LELC are relatively rare in the stomach. In particular, the clinicopathological features and outcome of gastric ADC-FG are not fully understood at present. Herein, we report the case of a patient with concurrent gastric ADC-FG and LELC.

\section{Case Report}

The patient was a 69-year-old man who had undergone endoscopic submucosal dissection for conventional gastric adenocarcinoma 13 years earlier. During follow-up evaluation, two different masses were identified in the stomach. Endoscopic examination revealed that the mass in the lower body was a huge ulceroinfiltrative lesion with a dirty base, and the mass in the upper body was a 2.4-cm-sized submucosal lesion with surface erosion (fig. 1). In the space between the two lesions, no abnormalities were recognized. These observations indicated that the mass in the lower body was a typical advanced gastric tumor, derived from epithelial cells, and the mass in the upper body appeared to be a submucosal tumor of nonepithelial cell origin, such as a gastrointestinal stromal tumor or leiomyoma. The huge mass in the lower body was biopsied and histologically demonstrated to be a poorly differentiated adenocarcinoma with lymphoepithelioma-like features.

The patient underwent a total gastrectomy. The resected stomach exhibited two separate masses, measuring $7.5 \times 7.0 \mathrm{~cm}$ in size in the lower body and $2.5 \times 1.5 \mathrm{~cm}$ in size in the upper body, respectively (fig. 2).

Microscopically, the lower-body tumor was characterized by poorly developed tubular structures and sheets or nests of round to polygonal cells associated with prominent lymphoid infiltration of the stroma. Tumor invasion of the serosa was observed, but no lymphovascular or perineural invasion was identified. Tumor cells showed an intensive nuclear signal for EBV by in situ hybridization (fig. 3). In contrast, the upper-body tumor was composed mainly of well-formed glands with occasional irregular anastomosing glands with columnar cells resembling fundic gland cells, predominantly chief cells, with basophilic cytoplasm and mildly enlarged nuclei showing atypia. This tumor was negative for EBV by in situ hybridization (fig. 4). These atypical glands were well circumscribed with an abrupt transition from the normal mucosa, which is one of the features of neoplasms. The nuclei were mildly enlarged, compared to those of normal fundic gland cells, and showed a mild 
Cha et al.: Concurrent Gastric Adenocarcinoma of Fundic Gland Type and Carcinoma with Lymphoid Stroma: A Rare Case Report

degree of pleomorphism with a few mitotic figures. The tumor invaded the muscularis propria layer, but lymphovascular and perineural invasion was absent.

Immunohistochemical staining for the mucin phenotype was performed. The following monoclonal antibodies were used: MUC2 (1:200; Novocastra Reagents, Leica Biosystems, Milton Keynes, UK) for intestinal goblet cells, MUC5AC (1:300; Novocastra Reagents) for gastric foveolar cells, MUC6 (1:300; Novocastra Reagents) for gastric mucous neck cells and pyloric glands, and CD10 (1:100; Novocastra Reagents) for small intestinal brush border. Immunohistochemistry was carried out on serial 4- $\mu$ m-thick paraffin blocks using the BOND-MAX system (Leica Biosystems) with EDTA buffer and diaminobenzidine as the chromogen according to the manufacturer's recommended protocol. The expression of the antigens was assessed as positive or negative. The immunoreactivity was defined as positive when the staining was recognized in more than $10 \%$ of the tumor cells [6].

The two tumors represented different mucin phenotypes. Immunohistochemical results for the cell differentiation are summarized in table 1. In the lower-body mass, MUC2, MUC5AC, MUC6, and CD10 were all negative (data not shown). On the other hand, in the upper-body mass, staining was positive for MUC6 but negative for MUC2, MUC5AC, and CD10 (fig. 5).

Based on the histological and immunohistochemical features, the mass located in the lower body was diagnosed as LELC and the mass in the upper body was revealed as ADC-FG. The remaining gastric tissue was unremarkable, and perigastric lymph node metastases were absent.

\section{Discussion}

Both gastric ADC-FG and LELC are relatively rare. In particular, ADC-FG is a recently recognized pathologic subtype of gastric adenocarcinoma. Although gastric ADC-FG remains incompletely understood to date, 10 cases of gastric ADC-FG (chief cell predominant type) characterized by Ueyama et al. [6] were found to have several particular clinicopathologic features, such as tumor location, histologic findings, specific phenotype, and low-grade malignancy. Histologically, gastric ADC-FG is a well-differentiated adenocarcinoma composed of atypical columnar cells mimicking fundic glands (mainly chief cells and a few scattered parietal cells). Based on the dominant cells constituting the tumor, gastric ADC-FG is classified into chief cell type, parietal cell type, and mixed type. In addition to morphological histological features, the differentiation of tumor cells can be assessed through the use of immunohistochemical stains. In the present case, the diffuse and strong expression of MUC6 was observed in the upper-body tumor. MUC6 is a well-known marker of gastric mucous neck cells and pyloric glands. In addition, it is expressed in chief cells of fundic glands [9]. Therefore, the expression of MUC6, as in our case, supported differentiation toward fundic glands, and our final diagnosis of ADC-FG is compatible.

In the previous studies, all cases of gastric ADC-FG were early-stage cancer with mucosal or submucosal invasion $[5,6,10]$. In contrast, the ADC-FG in our case was advanced-stage cancer with muscularis propria invasion. Nevertheless, it is similar to earlier reported cases with regard to absence of lymphovascular invasion, perineural invasion, and lymph node metastases. Some authors have proposed that this lesion is best regarded as benign and reclassified as oxyntic gland polyp/adenoma [5]. However, this seems unfounded on the basis of the findings of nuclear pleomorphism and invasion of the muscularis propria. It is more suitable to consider ADC-FG as low-grade malignancy. 
Cha et al.: Concurrent Gastric Adenocarcinoma of Fundic Gland Type and Carcinoma with Lymphoid Stroma: A Rare Case Report

Gastric LELC is a rare variant of gastric carcinoma that was first explained by Watanabe et al. [7] in 1976 as gastric carcinoma with a lymphoid stroma. LELC is known as EBVassociated carcinoma. An etiologic relationship of EBV is based on an even expression of EBV in tumor cells, in contrast to its absence in normal epithelium and dysplastic lesions [11]. Watanabe and colleagues suggested that accompanying lymphocytic infiltrates to the stroma might be caused by host defense responses. The mechanism by which EBV contributes to carcinogenesis remains unclear [12]. In the case discussed here, the LELC lesion in the lower body demonstrated diffuse EBV expression. Interestingly, the synchronous ADC-FG lesion was completely negative for EBV by in situ hybridization. On the basis of this result, we know that the two lesions have a different pathogenesis.

The incidence of multiple carcinomas appears to be higher in EBV-associated gastric carcinomas than in EBV-negative carcinomas [13]. EBV positivity has been reported to be higher in synchronous multiple carcinomas than in consecutive single carcinomas [14, 15]. The tumors in our case were two synchronous masses, one of which was EBV-positive LELC.

It has been known that gastric LELC generally has better prognosis than conventional gastric carcinomas. In addition, the natural course of ADC-FG is reportedly better than that of typical gastric carcinomas. Considering these facts, despite limited data, it is inferred that the prognosis for the patient described here may be more favorable than that for patients with usual gastric carcinomas. However, although neither lymphovascular invasion nor lymph node metastasis was present in this case, this patient did have advanced T-stage disease, especially in an area of ADC-FG that tended to be limited to the submucosa in previous reports. Therefore, further studies should be conducted to clarify the pathogenesis of these lesions and their natural history.

Not only LELC but also ADC-FG are uncommon histologic variants of gastric cancers. Furthermore, it is extremely rare that gastric LELC and ADC-FG occur synchronously and independently. We reported this rare case of concurrent gastric ADC-FG and LELC.

\section{Statement of Ethics}

This subject was obtained with informed consent under institutional review boardapproved protocols.

\section{Disclosure Statement}

The authors declare no conflicts of interest.

\section{References}

1 Lauren P: The two histological main types of gastric carcinoma: diffuse and so-called intestinal-type carcinoma. Acta Pathol Microbiol Scand 1965;64:31-49.

2 Nakamura K, Sugano H, Takagi K: Carcinoma of the stomach in incipient phase: its histogenesis and histological appearances. Gann 1968;59:251-258.

3 Kabashima A, Yao T, Sugimachi K, Tsuneyoshi M: Gastric or intestinal phenotypic expression in the carcinomas and background mucosa of multiple early gastric carcinomas. Histopathology 2000;37:513-522.

4 Tsukamoto T, Yokoi T, Maruta S, Kitamura M, Yamamoto T, Ban H, Tatematsu M: Gastric adenocarcinoma with chief cell differentiation. Pathol Int 2007;57:517-522. 


\section{Case Reports in \\ Gastroenterology}

\begin{tabular}{l|l}
\hline Case Rep Gastroenterol 2016;10:292-301 \\
\hline $10.1159 / 000444277$ & $\begin{array}{l}\text { C 2016 The Author(s). Published by S. Karger AG, Basel } \\
\text { www.karger.com/crg }\end{array}$ \\
\hline
\end{tabular}

Cha et al.: Concurrent Gastric Adenocarcinoma of Fundic Gland Type and Carcinoma with Lymphoid Stroma: A Rare Case Report

5 Singhi AD, Lazenby AJ, Montgomery EA: Gastric adenocarcinoma with chief cell differentiation: a proposal for reclassification as oxyntic gland polyp/adenoma. Am J Surg Pathol 2012;36:1030-1035. Ueyama H, Yao T, Nakashima Y, Hirakawa K, Oshiro Y, Hirahashi M, et al: Gastric adenocarcinoma of fundic gland type (chief cell predominant type): proposal for a new entity of gastric adenocarcinoma. Am J Surg Pathol 2010;34:609-619.

7 Watanabe H, Enjoji M, Imai T: Gastric carcinoma with lymphoid stroma: its morphologic characteristic and prognostic correlations. Cancer 1976;38:232-243.

8 Grogg KL, Lohse CM, Pankratz VS, Halling KC, Smyrk TC: Lymphocyte-rich gastric cancer: association with Epstein-Barr virus, microsatellite instability, histology and survival. Mod Pathol 2003;16:641-651.

9 Suzuki S, Tsuyama S, Murata F: Cells intermediate between mucous neck cells and chief cells in rat stomach. Cell Tissue Res 1983;233:475-84.

10 Park ES, Kim YE, Park CK, Yao T, Kushima R, Kim KM: Gastric adenocarcinoma of fundic gland type: report of three cases. Korean J Pathol 2012;46:287-291.

11 Beek JV, Hausen AZ, Kranenbarg EK, Velde CJ, Middeldorp JM, Brule AJ, Meijer CJ, Bloemena E: EBVpositive gastric adenocarcinomas: a distinct clinicopathologic entity with a low frequency of lymph node involvement. J Clin Oncol 2004;22:664-670.

12 Kang GH, Lee S, Kim WH, Lee HW, Kim JC, Rhyu MG, Ro JY: Epstein-Barr virus-positive gastric carcinoma demonstrates frequent aberrant methylation of multiple genes and constitutes $\mathrm{CpG}$ island methylator phenotype-positive gastric carcinoma. Am J Pathol 2002;160:787-794.

13 Fukayama M, Ushiku T: Epstein-Barr virus-associated gastric carcinoma. Pathol Res Pract 2011;207:529-537.

14 Tokunaga M, Land CE, Uemura Y, Tokudome T, Tanaka S, Sato E: Epstein-Barr virus in gastric carcinoma. Am J Pathol 1993;143:1250-1254.

15 Chang MS, Lee HS, Kim HS, Kim SH, Choi SI, Lee BL, Kim CW, Kim YI, Yang M, Kim WH: Epstein-Barr virus and microsatellite instability in gastric carcinogenesis. J Pathol 2003;199:447-452. 
Cha et al.: Concurrent Gastric Adenocarcinoma of Fundic Gland Type and Carcinoma with Lymphoid Stroma: A Rare Case Report
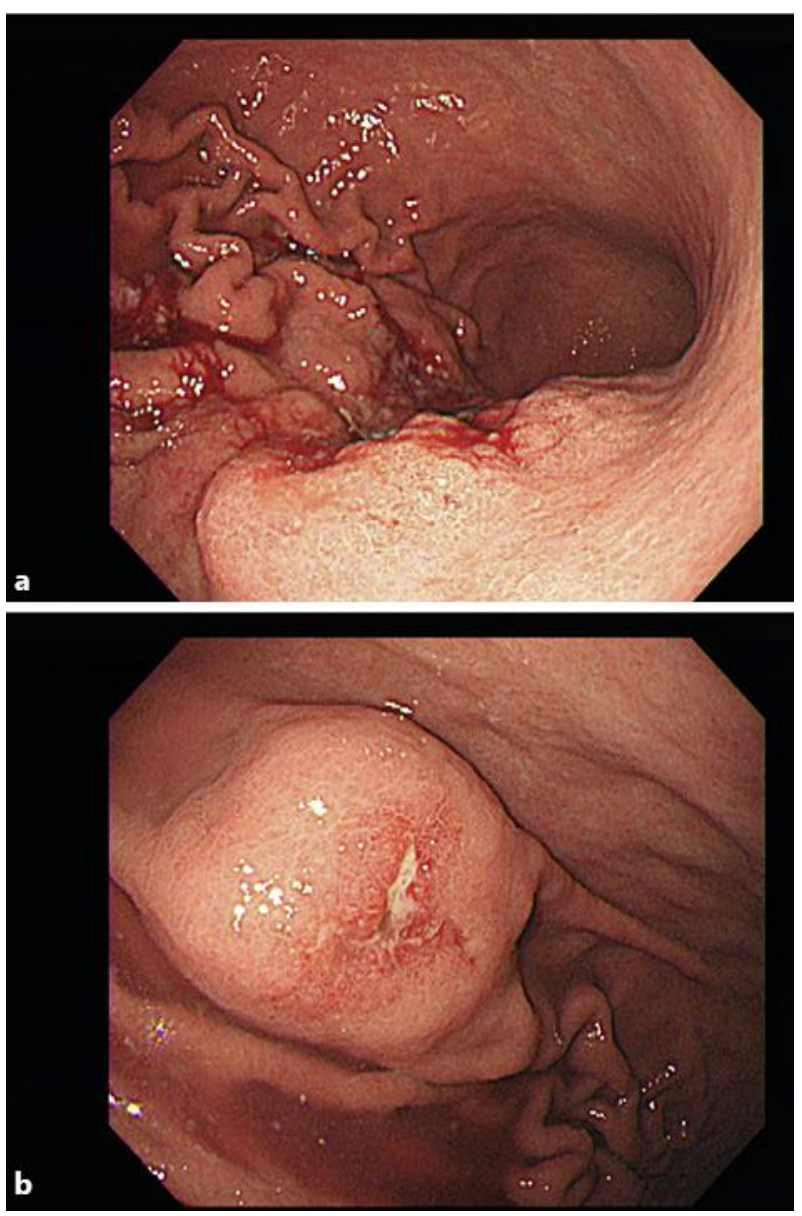

Fig. 1. Endoscopic observation revealing two masses: one of them was a huge ulceroinfiltrative mass located in the lower body (a) and the other was a submucosal mass with surface ulceration placed in the upper body (b). 
Cha et al.: Concurrent Gastric Adenocarcinoma of Fundic Gland Type and Carcinoma with Lymphoid Stroma: A Rare Case Report

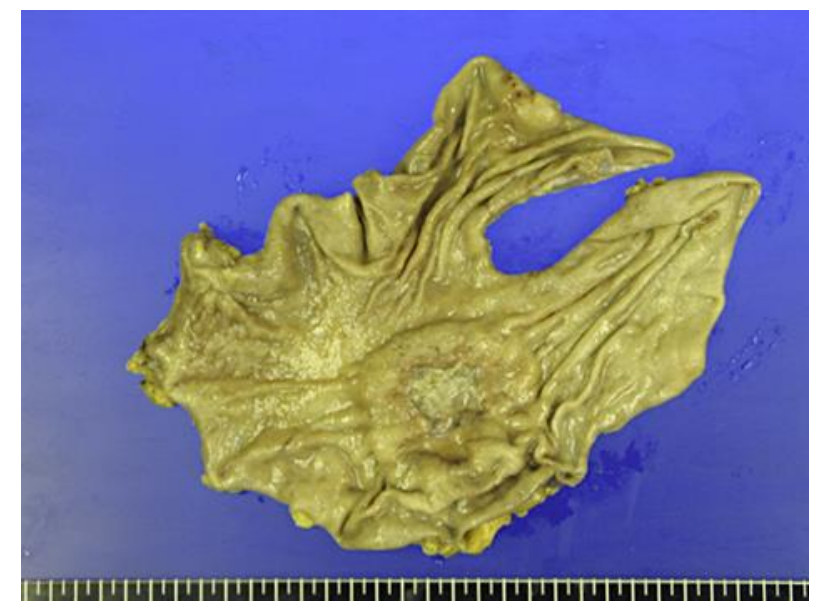

Fig. 2. Gross finding revealing two separate masses in the upper and lower body of the stomach, respectively. 


\begin{tabular}{|c|c|c|}
\hline \multirow{2}{*}{$\begin{array}{r}\text { Case Reports in } \\
\text { Gastroenterology }\end{array}$} & \multicolumn{2}{|c|}{ Case Rep Gastroenterol 2016;10:292-301 } \\
\hline & 10.1159/000444277 & $\begin{array}{l}\text { (c) } 2016 \text { The Author(s). Published by S. Karger AG, Basel } \\
\text { www.karger.com/crg }\end{array}$ \\
\hline
\end{tabular}

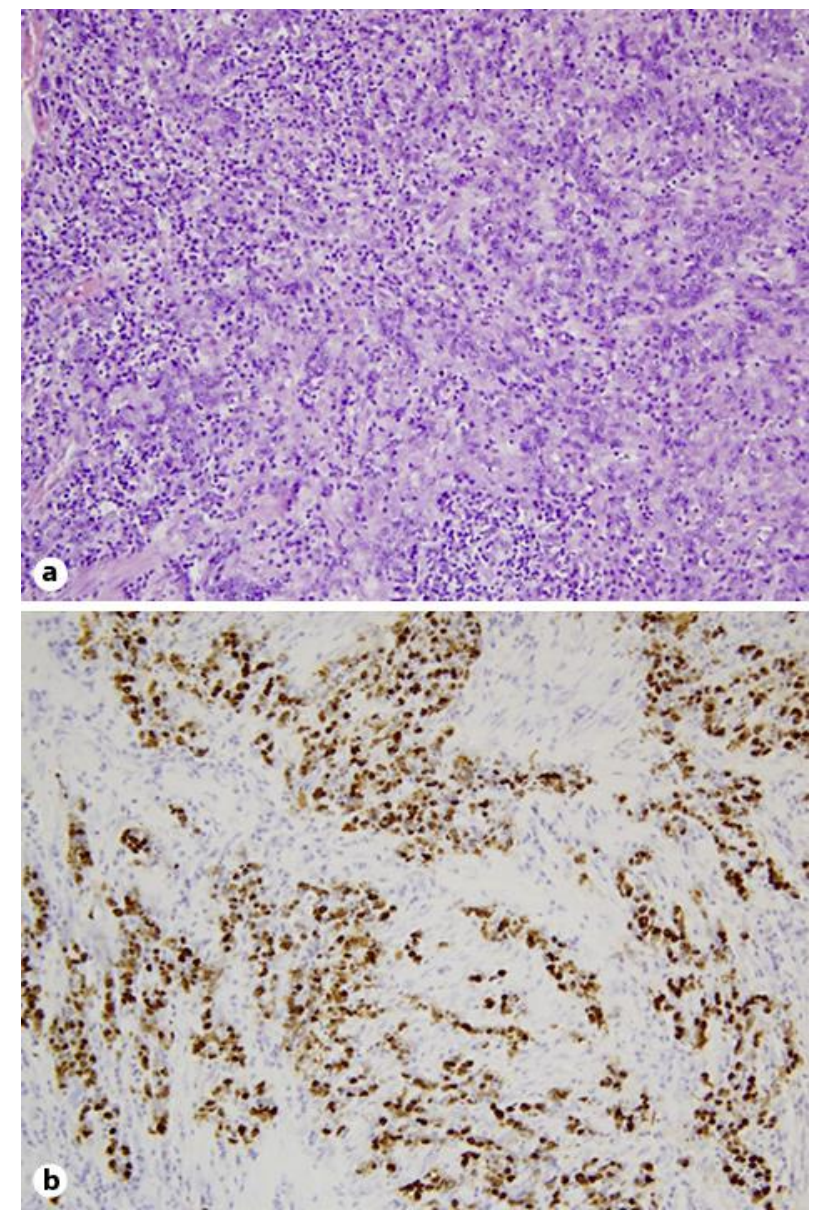

Fig. 3. a The lower-body tumor, diagnosed as LELC, was a poorly differentiated carcinoma with prominent lymphoid stroma. H\&E. $\times 200$. b Tumor cells of the lower body showed diffuse and strong positivity for EBV by in situ hybridization. $\times 200$. 


\begin{tabular}{ll|l} 
Case Reports in & \begin{tabular}{l} 
Case Rep Gastroenterol 2016;10:292-301 \\
\cline { 2 - 3 } Gastroenterology
\end{tabular} & $\begin{array}{l}\text { ○ 2016 The Author(s). Published by S. Karger AG, Basel } \\
\text { www.karger.com/crg }\end{array}$ \\
\cline { 2 - 2 } & $\begin{array}{l}\text { Cha et al.: Concurrent Gastric Adenocarcinoma of Fundic Gland Type and Carcinoma } \\
\text { with Lymphoid Stroma: A Rare Case Report }\end{array}$
\end{tabular}

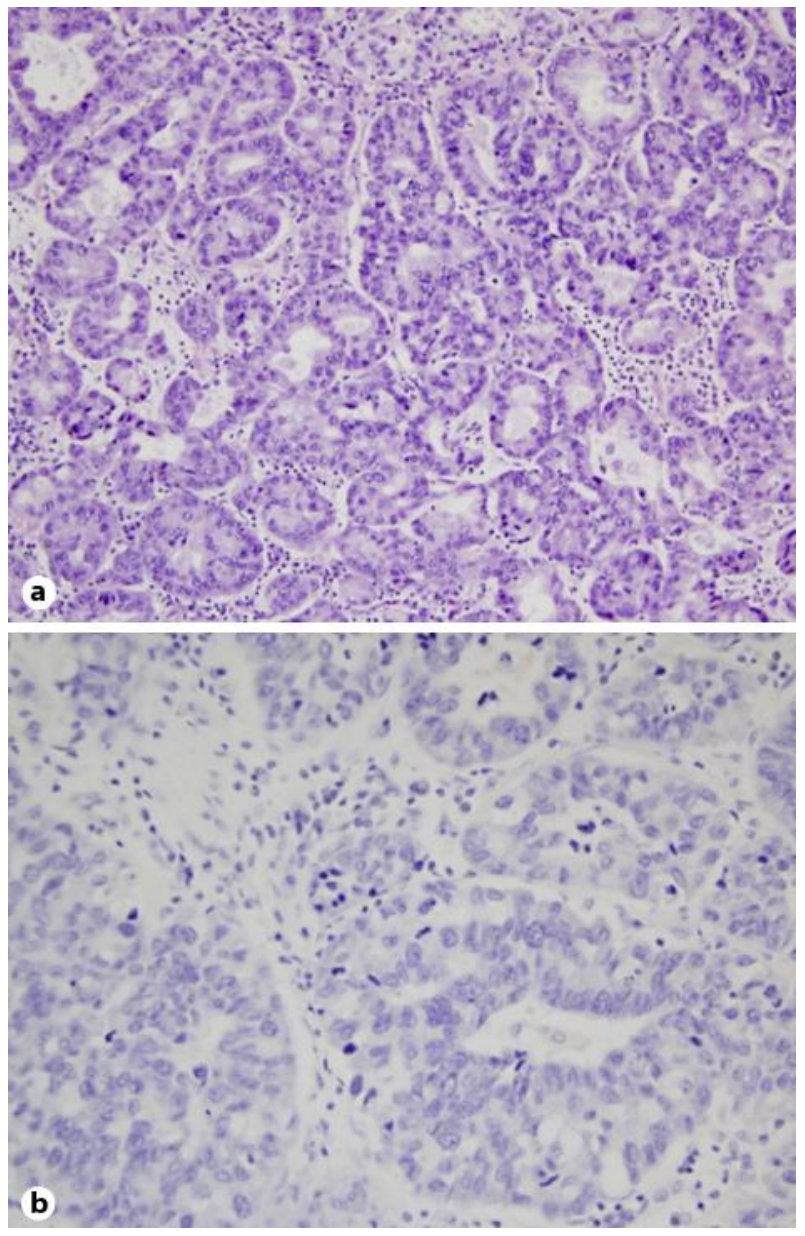

Fig. 4. a The upper-body tumor, diagnosed as ADC-FG, was a well-differentiated carcinoma, reminiscent of fundic gland cells. H\&E. $\times 200$. $\mathbf{b}$ Tumor cells of the upper body were negative for EBV by in situ hybridization. $\times 400$. 


\section{Case Reports in \\ Gastroenterology}

\begin{tabular}{l|l}
\hline Case Rep Gastroenterol 2016;10:292-301 \\
\hline $10.1159 / 000444277$ & $\begin{array}{l}\text { @ 2016 The Author(s). Published by S. Karger AG, Basel } \\
\text { www.karger.com/crg }\end{array}$ \\
\hline
\end{tabular}

Cha et al.: Concurrent Gastric Adenocarcinoma of Fundic Gland Type and Carcinoma with Lymphoid Stroma: A Rare Case Report
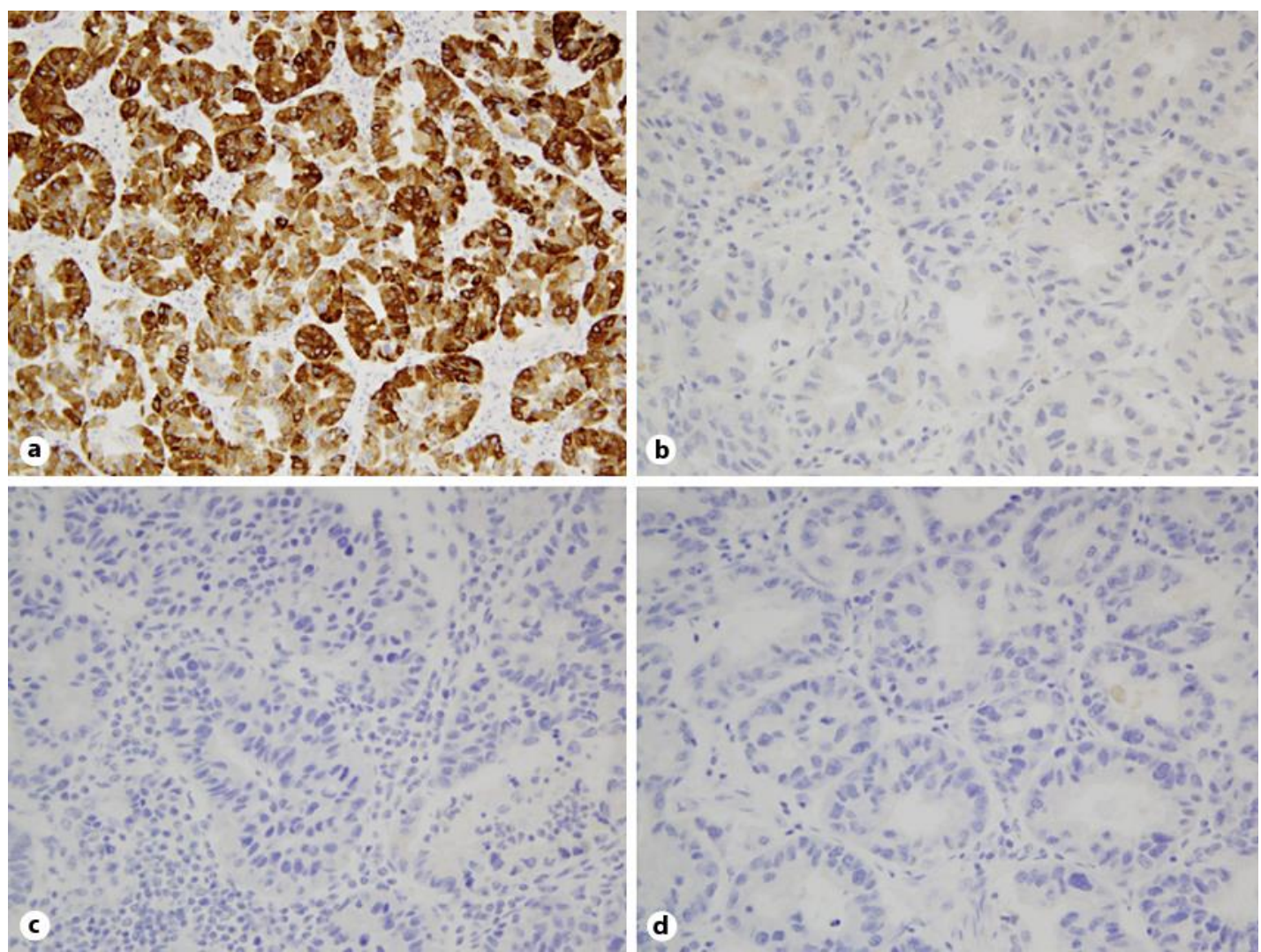

Fig. 5. Mucin expression of the ADC-FG. Tumor cells exhibited positivity for MUC6 (a) but negativity for CD10 (b), MUC2 (c), and MUC5AC (d). $\times 200$.

Table 1. Immunohistochemical results for the two different lesions

\begin{tabular}{lll}
\hline Antibody & LELC & ADC-FG \\
\hline MUC2 & negative & negative \\
MUC5AC & negative & negative \\
MUC6 & negative & positive \\
CD10 & negative & negative \\
EBV in situ hybridization & positive & negative \\
\hline
\end{tabular}

